\title{
Root Causes and Consequences of Extreme Poverty in Northern Bangladesh
}

\author{
Ram Proshad Barman1*, Mousume Islam² \\ ${ }^{*}$ Assistant Professor, Department of Sociology, Begum Rokeya University, Rangpur, BANGLADESH \\ ${ }^{2}$ MSS, Department of Sociology, Begum Rokeya University, Rangpur, BANGLADESH \\ *(proshadram2400@gmail.com)
}

This journal is licensed under a Creative Commons Attribution-Noncommercial 4.0 International License (CC-BY-NC). Articles can be read and shared for noncommercial purposes under the following conditions:

- BY: Attribution must be given to the original source (Attribution)

- NC: Works may not be used for commercial purposes (Noncommercial)

This license lets others remix, tweak, and build upon your work non-commercially, and although their new works must also acknowledge you and be non-commercial, they don't have to license their derivative works on the same terms.

License Deed Link: http://creativecommons.org/licenses/by-nc/4.0/

Legal Code Link: http://creativecommons.org/licenses/by-nc/4.0/legalcode

$A B C$ Research Alert uses the CC BY-NC to protect the author's work from misuse.

\begin{abstract}
Poverty has always become major concern due to multifarious reasons in the Northern part of Bangladesh from the very earlier years of independent Bengal. The concoction of this study is to find out the root causes and consequence of extreme poverty in Northern Bangladesh. Following purposive sampling a survey is conducted at 8 villages of Kurigram district from October December 2019. In addition, the researcher distributed a total of 106 surveys to respondents for analyzing and interpreting target population. The study revealed that the most vulnerable groups in the selected area were agricultural wage laborer's, landless and marginal farmers, children, women and aged people while food shortages, livelihood patterns, lack of industry, extreme unemployment and overall dependency associated with poverty scales and such states create more penetration on these community. The study concluded that hazardous events, Monga situation, resource scarcity, poor socio-economic structure and underdeveloped infrastructure solely deployed extreme poverty in the study region. Lastly, it is also designed to suggest how to reduce the extreme poverty following various poverty reduction programs by NGOs and government of Bangladesh using measurement scales towards standard livelihood in northern region.
\end{abstract}

\section{Keywords}

Poverty, Cause, Consequence, Extreme, Northern Bangladesh

\subsection{INTRODUCTION}

Since independence Bangladesh has been struggling to feed its increasing population and a dire necessity is to increase crops production. While it is considered as one of the disaster-prone countries in the world having about 149.77 million people within an area of $147,570 \mathrm{Km} 2$ and growth rate of population is 1.37 (BBS, 2012). Again, floodplain topography and tropical monsoon climate makes northern region of Bangladesh vulnerable owing to various natural calamities including flood, riverbank erosion, drought, cold waves and all of which occurs more frequently and intensely than other regions of the country (Paul, 2014). Even in Bangladesh, 25\% hardcore or ultra-core poor face severe food insecurity every year, $41 \%$ are living below the poverty line and $20 \%$ are estimated to belong to be 
hardcore poor (MoF, 2010). With these compelling conditions, economic diversification, heavily dependence on agriculture, survival of landless and poorest people on agriculture by selling labor, changing of climate, less working opportunities of people strengthening poverty and hunger situation which also termed as seasonal poverty in the north (Elahi \& Ara, 2008). Generally, in the months of September to November extreme poverty or Monga occurs for variety of reasons; high number of poor households, inequitable distribution of land, overall dependency on agricultural labor for their subsistence, limited opportunities for sustainable off-farm economic activities and natural calamities (Zug, 2006).

Earnestly, the poverty influenced a lot to the lives of the people while rural people go to cities; to pull rickshaw, sell labor power in the factory like garments, multinational companies and to reduce the quantity of nutritional intake, to earn the amount of meals for family. Only due to poor socio-economic structure people just try to consume cheap and sometimes unhygienic products. It should be regarded that for the causality of poverty number of studies have focused on famine in Bangladesh (Sen, 1984), few researcher focused on the food production in Bangladesh (Karim \& Levinson, 1979) while others on food planning and scarcity (Chen, 1975), while some argued on agricultural production, landlessness and seasonality (Roy, 1996;) and few criticized about government role to deal with these issues (Hye, 2002).

Even Government, Non-government and International Organizations show very little fruitful attention in the northern Bangladesh instead of such overwhelming silent disaster occurs very often creating people vulnerable from early years. Therefore, to fill this research gap the author designed to focus the following objectives;

- To identify the root causes of extreme poverty

- To find out the major consequences of poverty experienced in the area

- To recommend the policy guidelines of poverty reduction

Finally, the study will be helpful to find out the real scenario of extreme poverty in the north while the policy makers, the social workers, the social activist can utilize the recommendations and the results associated with such research further.

\subsection{LITERATURE REVIEW}

In a study conducted by Farrington et.al (2007), examined the evidences of poverty through the links between social protection and agricultural growth in Bangladesh by synthesizing existing impact evaluations from such programmes e.g. protection measures, prevention measures and promotion measures. Shofi Ullah Mazumder and Lu Wencong (2012) conducted a research in the five northern districts of Bangladesh where Monga affected people were mostly concentrated. He found that about $69.76 \%$ of the respondents opined that Monga happens in the greater Rangpur region because of frequently occurring natural calamities and having no work opportunity in the lean season.

Over $60 \%$ viewed that the timing of Monga commences in mid-September and ends in mid-November and it happens almost every year. About $86 \%$ of the respondents reported Monga either as 'moderately vulnerable' or 'most vulnerable' and $62 \%$ noted it as 'increasing'. Almost $50 \%$ of the respondents could manage only one meal a day during the Monga period and $60 \%$ had to remain in occasional starvation very frequently because of lack of purchasing capacity. As a result, most of them adopted a number of coping mechanisms like taking loan, eating less, government relief etc. to encounter with Monga (Mazumder \& Wencong, 2012).

In 2006, the Palli Karma-Sahayak Foundation (PKSF), a nonprofit wholesale lending agency in Bangladesh, launched a programme for Monga eradication with the aim of mitigating the impacts of extreme poor situation on rural households in north western parts of Bangladesh and able to generate diversified income sources to eradicate the extremity on an average (PKSF, 2006). In a study of Greeley (1997), presented a strong case for measuring poverty using food consumption-based indicators, especially when carrying out impact assessment work of microcredit programmes. There are several 
arguments are used to support the stance; the first was based on the hierarchy of needs notion and the second was impact assessment work (Greeley, 1997). A paper prepared by Dr. Debapriya Bhattacharya (2000) entitled 'poverty and reduction in Bangladesh' argued a need for conceptualizing and developing a holistic policy framework to strategically formulate policies, sequence intervention-instruments and implement projects and reforms to realize specific goals for poverty alleviation with a time bound framework (Bhattacharya \& Titumir,2000). Therefore, a strategy for poverty eradication demands; a multi-pronged- interventions; a pro-active role of the state and public policy and a realignment of donors' country programming and support to ensure that their priorities and assistance feed into the partner (recipient) government's overall strategy and medium-term expenditure plans.

CARE (2005) investigated on poverty and found that the northern region of Bangladesh topographically and climatically vulnerable due to floods, river erosions, drought spells and cold waves more frequently compared to other regions (CARE, 2005). Again, another researcher argued that extreme poverty can be used in Bangladesh to describe the overall impact of a combination of factors at the household level, e.g. the reduction in day labor opportunities after the rice crop is sown and before the harvest, effects of monsoon flooding, prices higher of commodities, diseases affect the locality, lack of work, insecurity of social protection, available food and agricultural production at larger context (DER, 2004).

\subsection{METHODOLOGY}

\subsection{The Nature of the Study}

The Northern Kurigram district was selected as study region owing to the socio-economic factor available for the researcher. The study was quantitative in nature, was focused on an in-depth understanding of the nature, root causes and consequences of poverty. The survey inquiries relationship with other factors to relevancy of extremity of poverty, reduction of poverty and economic factors.

\subsection{Data Collection}

By using purposive sampling technique, a total of 106 respondents are agreed to be interviewed from the Sadar Upazila of Kurigram region who has worst experience and practical knowledge about adaptation of the extreme and hardcore poverty in the early years. While 15 graduates with prior experience of working in similar cases, were selected as data collectors in the area. Before going to the field, they were effectively trained on multifarious issues including techniques of interviewing, ethics, rapport building and were strictly supervised during the entire data collection period. Interviews were conducted over in Bengali language and later translated into English. In order to maintain credibility, to ensure accuracy and appropriate representation of the respondents the transcripts and translations rechecked narratively too. Lastly, a small gift was offered to each respondent for their valuable time for the interview.

\subsection{Data Analysis}

For data analysis, a thematic method was followed and after a meticulous analysis of all the transcripts, the texts were reinterpreted. Then the data were separated catering individual, familial and cultural factors based on their contribution to the causes and consequences of poverty in selected area. Consequently, phases of poverty were then grouped together for providing broad understandings its extremity broadly, as discussed in the results section.

\subsection{Ethical Considerations}

We, here strictly followed different ethical principles that were adopted in similar studies. Prior to conducting the research, each participant was clearly explained its aims and objectives. Besides, we also explained the reasons behind the personal and sensitive questions that were framed in the interview framework. 
However, they were given full liberty to end their participation from the interviews at any point. They could skip any uncomfortable questions if they felt the need to do so. Each participant was assured of privacy and confidentiality through the use of pseudonym. In some cases, our data collectors, who were well trained in counseling, responded appropriately to reduce and manage the emotional distress of the respondents.

\subsection{Limitations of the Study}

In general, for a critical and useful study, there might have some limitations and this study was not beyond such limitations. Notably, the data collected from respondents were not so verified and substantiated from other sources. There was a possibility that some respondents might have suppressed some facts or felt uncomfortable revealing personal and family details because of inherent cultural barriers.

\subsection{RESULTS AND DISCUSSIONS}

\subsection{Characteristics}

\begin{tabular}{|c|c|c|c|c|c|}
\hline \multicolumn{2}{|c|}{ Characteristics } & \multicolumn{2}{|c|}{ Counts (N) } & \multicolumn{2}{|c|}{ Percentages $(\%)$} \\
\hline Gender & $\begin{array}{l}\text { Male } \\
\text { Female }\end{array}$ & $\begin{array}{l}66 \\
40 \\
\end{array}$ & Total 106 & $\begin{array}{l}62.3 \\
37.3 \\
\end{array}$ & Total 100 \\
\hline Age & $\begin{array}{l}11-20 \text { years } \\
21-30 \text { years } \\
31-40 \text { years } \\
41-50 \text { years } \\
51-60 \text { years }\end{array}$ & $\begin{array}{c}9 \\
35 \\
35 \\
12 \\
15\end{array}$ & Total 106 & $\begin{array}{c}8.5 \\
33.0 \\
33.0 \\
11.3 \\
14.3\end{array}$ & Total 100 \\
\hline Education & $\begin{array}{l}\text { Illiterate } \\
\text { Primary } \\
\text { Secondary } \\
\text { H. Secondary } \\
\text { Honors } \\
\text { Masters } \\
\end{array}$ & $\begin{array}{c}15 \\
36 \\
24 \\
20 \\
9 \\
2\end{array}$ & Total 106 & $\begin{array}{c}14.2 \\
34.0 \\
22.6 \\
18.9 \\
8.5 \\
1.9 \\
\end{array}$ & Total 100 \\
\hline Village & $\begin{array}{l}\text { Kumar Para } \\
\text { Pal Para } \\
\text { Nawa Para } \\
\text { Velkopa } \\
\text { Krishnapur } \\
\text { Saodagar Para } \\
\text { Baharer Char } \\
\text { Garer Par }\end{array}$ & $\begin{array}{c}9 \\
11 \\
10 \\
23 \\
25 \\
8 \\
8 \\
12\end{array}$ & Total 106 & $\begin{array}{c}8.5 \\
10.4 \\
9.4 \\
21.7 \\
23.6 \\
7.5 \\
7.5 \\
11.3 \\
\end{array}$ & Total 100 \\
\hline $\begin{array}{l}\text { Monthly } \\
\text { Income }\end{array}$ & $\begin{array}{l}\text { Less than } 1000 \\
\text { TK } \\
1000-1900 \text { TK } \\
2000-3900 \text { TK } \\
4000-4900 \text { TK } \\
5000+\text { TK }\end{array}$ & $\begin{array}{c}42 \\
28 \\
22 \\
8 \\
6\end{array}$ & Total 106 & $\begin{array}{c}40 \\
27 \\
21 \\
8 \\
4\end{array}$ & Total 100 \\
\hline
\end{tabular}

Table 1: Information of the Respondent

The above table 1 represents overall information of the study. There are five characteristics; however, it shows male $62.3 \%$ and female $37.3 \%$. In the age variation, most of the participants belong to $21-40$ years old while majority of the respondents completed just primary school that reflect $34 \%$ and $22.6 \%$ completed secondary school certificate.

While few of them belongs to higher education because of social structure. As noted earlier, the researcher collected data from 8 villages of Sadar Upazilla of Kurigram district and highest 25 people $(23.6 \%)$ are interviewed from Krishnapur village and $21.7 \%$ are taken from Velkopa village. As they involve to agriculture that's why their monthly income between 1000 to 5000 BD TK and $40 \%$ participants earned less than 1000 BD TK per month. 


\subsection{Factors contributing to generate poverty e.g. disaster, dependency and inadequate industry}

There are several factors that generate poverty in some cases in the selected area of Kurigram and natural disaster is one of them. Historically and topographically flood (52\%, table-2), visits the region every year creating much more complexity for the poor people. Again, drought and cyclone add something extra pressures to the livelihood of the poor as well. Even the people want government job $(36.8 \%)$ that also causes unemployment and lastly leads to family conflict.

In this modern society, industry can contribute by creating available working opportunity what is absent in this region. Although they have cheap labor (40.5\%), easy labor (36.5\%), they can't establish industry due to capitals and lack of entrepreneurs. However, natural disaster along with over dependency on agriculture $(36.8 \%)$ contribute to regenerate poverty.

\begin{tabular}{|c|c|c|c|c|c|c|c|c|c|c|c|}
\hline \multicolumn{2}{|c|}{ Variable } & $\mathrm{N}$ & $\%$ & \multicolumn{2}{|c|}{ Variable } & $\mathrm{N}$ & $\%$ & \multicolumn{2}{|r|}{ Variable } & $\mathrm{N}$ & $\%$ \\
\hline \multirow{5}{*}{ 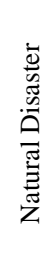 } & Flood & 55 & 52 & \multirow{5}{*}{$\begin{array}{l}\overrightarrow{0} \\
\text { एँ } \\
\overline{0} \\
\overline{0} \\
\overline{0} \\
\overline{0} \\
\overline{0}\end{array}$} & Agriculture & 39 & 36.8 & \multirow{5}{*}{ 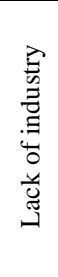 } & Cheap labor & 42 & 40.5 \\
\hline & Drought & 20 & 19 & & $\begin{array}{c}\text { Not } \\
\text { innovative }\end{array}$ & 20 & 18.9 & & Easy labor & 38 & 36.5 \\
\hline & Famine & 15 & 14 & & $\begin{array}{l}\text { Job as } \\
\text { passion }\end{array}$ & 34 & 32.1 & & $\begin{array}{c}\text { Lack of entrepre- } \\
\text { neur }\end{array}$ & 15 & 13 \\
\hline & Cyclone & 16 & 15 & & $\begin{array}{l}\text { Disequilib- } \\
\text { rium }\end{array}$ & 13 & 12.3 & & Exploitation & 11 & 9.5 \\
\hline & Total & 106 & 100 & & Total & 106 & 100 & & Total & 106 & 100 \\
\hline
\end{tabular}

Table 2: How disaster, dependency and inadequate industry cause poverty

\subsection{Contribution of culture, social structure and unemployment to generate poverty}

\begin{tabular}{|c|c|c|c|c|c|c|c|c|c|c|c|}
\hline \multicolumn{2}{|r|}{ Variable } & $\mathrm{N}$ & $\%$ & \multicolumn{2}{|c|}{ Variable } & $\mathrm{N}$ & $\%$ & \multicolumn{2}{|r|}{ Variable } & $\mathrm{N}$ & $\%$ \\
\hline \multirow{5}{*}{ 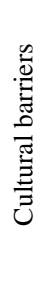 } & Need govt. job & 43 & 42 & \multirow{5}{*}{ 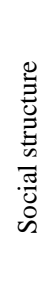 } & $\begin{array}{c}\text { Unskilled } \\
\text { manpower }\end{array}$ & 49 & 47 & \multirow{5}{*}{ 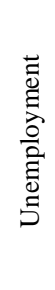 } & Burden of family & 33 & 31 \\
\hline & $\begin{array}{l}\text { Blaming } \\
\text { fortune }\end{array}$ & 20 & 19 & & $\begin{array}{c}\text { Poor will- } \\
\text { power }\end{array}$ & 32 & 30 & & Lack of income & 53 & 51 \\
\hline & $\begin{array}{l}\text { Obsolete } \\
\text { custom }\end{array}$ & 28 & 26 & & $\begin{array}{c}\text { poor } \\
\text { mentality }\end{array}$ & 20 & 18 & & Social disorder & 18 & 17 \\
\hline & $\begin{array}{l}\text { Inheritance } \\
\text { occupation }\end{array}$ & 15 & 13 & & $\begin{array}{c}\text { Social } \\
\text { conflict }\end{array}$ & 5 & 5 & & Rise of debt & 2 & 1 \\
\hline & Total & 106 & 100 & & Total & 106 & 100 & & Total & 106 & 100 \\
\hline
\end{tabular}

Table 3: how culture, social structure, unemployment cause poverty

The following table 3 represents the cultural barriers. e.g. people badly desire government job (42\%) setting as passion, ignoring truth they blame their faith (19\%) and practicing obsolete custom like 'we are poor and we can't do anything'. For these reasons, social structures are also responsible for poverty because most of the people are unskilled (47\%), they just can maintain agriculture and can't come out from such tradition.

Although few of them try to get job, only due to poor will power (30\%) can't succeed in some cases. Again, due to inability of income when someone is considered as burden of family gets frustrated and enlisted as unemployed. Currently such pictures have been common in Monga prone areas.

\subsection{Relationship among politics, climatic change and socio-economic condition with poverty}

To find out the relationship between extreme poverty and socio-economic conditions, the researcher asks the respondent about their reasons of vulnerability. Most of the people sell labor power (38\%) and $36 \%$ are landless or tenure farmer and affected by various diseases $(18 \%)$. There is also political influence while $47 \%$ says they are powerless and dominated by political leader, they are being exploited (14\%) directly or indirectly. 
False consciousness (23\%) is also developed by some people to earn public sympathy for controlling general people. It is also true that climatic change creates more vulnerability (37\%) in the area, forcing people to migrate $(40 \%)$ and as a result people get loan (17\%) for adapting new environment and in some areas, respondents change their profession (6\%) what ultimately disrupts their normal situation.

\begin{tabular}{|c|c|c|c|c|c|c|c|c|c|c|c|}
\hline \multicolumn{2}{|c|}{ Variable } & $\mathrm{N}$ & $\%$ & \multicolumn{2}{|c|}{ Variable } & $\mathrm{N}$ & $\%$ & \multicolumn{2}{|c|}{ Variable } & $\mathrm{N}$ & $\%$ \\
\hline \multirow{5}{*}{ 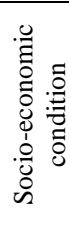 } & Sell labor & 40 & 38 & \multirow{5}{*}{ 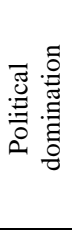 } & $\begin{array}{c}\text { Mass } \\
\text { exploitation }\end{array}$ & 15 & 14 & \multirow{5}{*}{ 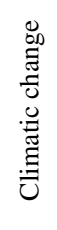 } & Vulnerability & 39 & 37 \\
\hline & Landless & 38 & 36 & & Inequality & 17 & 16 & & Migration & 42 & 40 \\
\hline & Diseases & 19 & 18 & & Powerless & 49 & 47 & & Loan & 18 & 17 \\
\hline & Religious & 9 & 8 & & $\begin{array}{c}\text { False } \\
\text { awareness }\end{array}$ & 25 & 23 & & $\begin{array}{l}\text { Change pro- } \\
\text { fession }\end{array}$ & 7 & 6 \\
\hline & Total & 106 & 100 & & Total & 106 & 100 & & Total & 106 & 100 \\
\hline
\end{tabular}

Table 4: how socio-economic condition, politics, climate change cause poverty

\subsection{Consequences of extreme poverty on migration, health and Societal crisis}

From the table 5 it is found that due to extreme poverty people of this area migrate from their living place to cities in order to lead a better live, fulfill their nutritional demand. While $15 \%$ respondents say they permanently migrate, seasonally migrate $27 \%$, internally $19 \%$ and externally migrate $15 \%$. Social crisis occurs when they feel insecurity (13\%), can't provide sufficient medical facilities $(14 \%)$ to their respective family members and more frequently agricultural productions (24\%) are reduced by calamities. When people suffer to food scarcity (39\%) and health hazards, consequences of extreme poverty clears everything. Because people are affected by high blood pressures $(36 \%)$, heart diseases are increased (22\%), few of them commit suicide (17\%). However, poverty affects their social and health issues seriously when they have scarcity what normally does for any community.

\begin{tabular}{|c|c|c|c|c|c|c|c|c|c|c|c|}
\hline \multicolumn{2}{|c|}{ Variable } & $\mathrm{N}$ & $\%$ & \multicolumn{2}{|c|}{ Variable } & $\mathrm{N}$ & $\%$ & \multicolumn{2}{|c|}{ Variable } & $\mathrm{N}$ & $\%$ \\
\hline \multirow{6}{*}{ 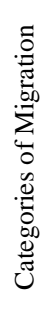 } & Temporary & 26 & 24 & \multirow{6}{*}{$\begin{array}{l}\frac{n}{0} \\
\frac{\pi}{0} \\
\frac{\pi}{0} \\
0\end{array}$} & $\begin{array}{c}\text { Food } \\
\text { scarcity }\end{array}$ & 41 & 39 & \multirow{6}{*}{ 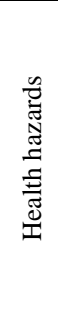 } & High blood & 37 & 36 \\
\hline & Seasonal & 28 & 27 & & Sheltering & 11 & 10 & & Heart disease & 24 & 22 \\
\hline & Internal & 21 & 19 & & $\begin{array}{l}\text { Less crops pro- } \\
\text { duction }\end{array}$ & 26 & 24 & & Suicide & 18 & 17 \\
\hline & External & 15 & 15 & & $\begin{array}{c}\text { Insufficient } \\
\text { Medical services }\end{array}$ & 15 & 14 & & Stomach & 15 & 14 \\
\hline & Permanent & 16 & 15 & & Insecurity & 13 & 13 & & Lung disease & 12 & 11 \\
\hline & Total & 106 & 100 & & Total & 106 & 100 & & Total & 106 & 100 \\
\hline
\end{tabular}

Table 5: Effects of extreme poverty on migration, social crisis and health

\subsection{Monga events and its longevity over the years}

It is also clear (table 6) that in the last 10 years Monga as extreme hardship of poverty occurred occasionally reflecting 1-2 times 36\%, 3-4 times 31\% and 9-10 times occurred 7\%. For these reasons, people are vulnerable and experience hardship phase of poverty that is difficult to recover. Again, when respondents are asked about longevity of Monga situation 44\% says Monga lasts about 2 months in a year that exclusively destroys people's living condition specially the poor and vulnerable.

For the meals they ensured that $29 \%$ people had less than 1 month, $26 \%$ had 2 months meals and while $14 \%$ said over than 4 months meals only. However, people experience Monga every year and it lasts long time and effects on their meals.

\begin{tabular}{|c|c|c|c|c|c|c|c|c|c|c|c|}
\hline \multicolumn{2}{|c|}{ Variable } & $\mathrm{N}$ & $\%$ & \multicolumn{2}{|c|}{ Variable } & $\mathrm{N}$ & $\%$ & \multicolumn{2}{|c|}{ Variable } & $\mathrm{N}$ & $\%$ \\
\hline \multirow{6}{*}{ 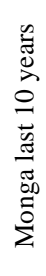 } & $1-2$ times & 38 & 36 & \multirow{6}{*}{ 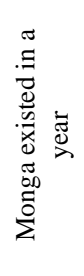 } & 1 month & 11 & 10 & \multirow{6}{*}{ 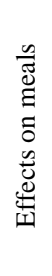 } & $\begin{array}{c}\text { Less than } 1 \\
\text { month }\end{array}$ & 31 & 29 \\
\hline & 3-4 times & 33 & 31 & & 2 months & 46 & 44 & & 2 months & 28 & 26 \\
\hline & $5-6$ times & 16 & 15 & & 3 months & 26 & 24 & & 3 months & 18 & 17 \\
\hline & 7-8 times & 12 & 11 & & 4 months & 10 & 9 & & 4 months & 15 & 14 \\
\hline & 9-10 times & 7 & 7 & & Over 4 months & 13 & 13 & & 4+ months & 14 & 14 \\
\hline & Total & 106 & 100 & & Total & 106 & 100 & & Total & 106 & 100 \\
\hline
\end{tabular}

Table 6: last 10 years Monga, its longevity and effects on meals in the study area 


\subsection{Linkages between poverty and poverty reduction programs through various organizations}

The following table shows that due to extreme poverty various programs are generated for poverty reduction including government projects (16\%), projects of international NGOs (11\%) and micro credit programs $(17 \%)$. While few vulnerary organizations also work there in order to reduce the number of poor people. Micro credit programs are run by local NGOs and these organizations take more interests as well such as $26 \%$ says they get loan from GRAMEEN BANK where $21 \%$ get loan from ASHA NGOs.

Moreover, these NGOs sometimes provide training on various fields that are so useful and positive for the region. In a nutshell, poverty directly or indirectly involves themselves to take training what helps them to come out from poverty cycle. The table shows that $34 \%$ people get training on poultry farming, $24 \%$ on fish cultivation and $19 \%$ get training on social forestation. Moreover, $14 \%$ people get training on animal husbandry where $9 \%$ get training on tailoring effectively that helps to reduce poverty. However, extreme poverty also influences them positively by involving to training to lead their livelihood.

\begin{tabular}{|c|c|c|c|c|c|c|c|c|c|c|c|}
\hline \multicolumn{2}{|c|}{ Variable } & $\mathrm{N}$ & $\%$ & \multicolumn{2}{|c|}{ Variable } & $\mathrm{N}$ & $\%$ & \multicolumn{2}{|c|}{ Variable } & $\mathrm{N}$ & $\%$ \\
\hline \multirow{6}{*}{ 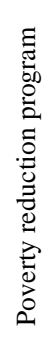 } & $\begin{array}{l}\text { Govt. } \\
\text { project }\end{array}$ & 17 & 16 & \multirow{6}{*}{ 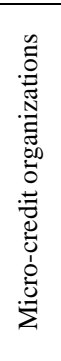 } & $\begin{array}{l}\text { GRAMEEN } \\
\text { BANK }\end{array}$ & 27 & 26 & \multirow{6}{*}{ 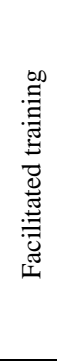 } & $\begin{array}{c}\text { Poultry } \\
\text { Farming }\end{array}$ & 35 & 34 \\
\hline & Local NGOs & 52 & 50 & & ASHA & 23 & 21 & & $\begin{array}{l}\text { Fish cultiva- } \\
\text { tion }\end{array}$ & 25 & 24 \\
\hline & Micro credit & 18 & 17 & & TMSS & 24 & 23 & & $\begin{array}{c}\text { Social } \\
\text { forestation }\end{array}$ & 21 & 19 \\
\hline & Int. NGO & 12 & 11 & & GUK & 19 & 17 & & $\begin{array}{c}\text { Animal } \\
\text { husbandry }\end{array}$ & 15 & 14 \\
\hline & $\begin{array}{c}\text { Voluntary } \\
\text { organization }\end{array}$ & 7 & 6 & & BRAC & 13 & 13 & & Tailoring & 10 & 9 \\
\hline & Total & 106 & 100 & & Total & 106 & 100 & & Total & 106 & 100 \\
\hline
\end{tabular}

Table 7: Poverty reduction program, micro-credit org. and facilitated training in the study area

\subsection{RECOMMENDATION}

In the research area, it was concerned previously that they are totally pauperized by extreme poverty hardship but with the passage of time it minimizes its nature. People of Kurigram are going to improve their condition from earlier periods. For policy implementations, people provide few important suggestions that should be taken care to reduce poverty from this region by following these;

- Determining the factors responsible for the increased propensity of natural disaster like flood, drought and more research should be carried out

- Initializing more safety net programs by better understanding the cause-and-effect relationship of poverty

- Ensuring women's participation in the all spheres of society providing employment opportunities to workplace

- Small scale handicraft industry along with interest free loan should be provided to new entrepreneurs

- Government should take more VGD programs, sustainable relief programs through various committee in the area

- Agricultural crops diversification, water tolerant crops and more training should provide to farmers by involving them from traditional to modern harvesting

- Developing infrastructure, ensuring medical facilities and creating self-employment should be given priority in the selected area

- Alternative earning sources should be available so that level of migration doesn't hamper the likelihood of the locality

- Most importantly, youth should be confident ignoring the Monga and should create favorable environment for living as other area desire 


\subsection{CONCLUSIONS}

The present study is a modest effort of identification of responsible causes and induced consequences of poverty among the vulnerable communities of Kurigram district. The study revealed that different forms of reasons associated with extreme poverty including natural disaster, cultural barriers, socio-economic insolvency, lack of employment, industry that deployed locality to poor situation from earlier years in northern Bangladesh. As a result, multifarious effects are experienced by the people of this region e.g. health hazards and societal vulnerabilities, food insecurity, Monga condition as fear, effects on meals, loan taking, more interest rate imposed by microcredit organizations and getting training on self-reliant program. Lastly, the suggestions from respondents are taken into consideration and few recommendations also added from researcher for further research, policy makers in the relevant field. However, only mutual understanding and cooperation through technological development extreme poverty can be reduced in the area.

\section{ACKNOWLEDGEMENTS}

This paper has been prepared from the research project submitted to Begum Rokeya University, Rangpur, Bangladesh entitled 'Is Monga an extreme hardship of Poverty in northern Bangladesh'. All primary data come mainly from the author's project fieldwork. The author would also like to thank the Begum Rokeya University authority, especially Honorable Vice chancellor sir and all teachers, staff, students of Sociology Department, BRUR and finally participants of the study.

\section{REFERENCES}

BBS (Bangladesh Bureau of Statistics). 2012. Population census, 2011, Final Report. Bangladesh Bureau of Statistics, Dhaka.

Bhattacharya, D. \& Titumir, R. 2000. Poverty Reduction in Bangladesh: Absence of a national framework, an abundance of donors' strategies. Centre for Policy Dialogue. House No 40/C, Road No 11, Dhanmondi R/A. Mailing Address: GPO Box 2129, Dhaka-1209, Bangladesh

CARE. 2005.Report on Monga in Northern Bangladesh, Dhaka.

Chen, L.C. 1975. An Analysis of per capita food grain availability, consumption and requirements in Bangladesh: A systematic approach to food planning. Journal of BIDS. 18(2): 101-124.

DER.2004. Report from the special DER Meeting on Monga 2004, Disaster and Emergency Response Group. Local Consultative group.

Elahi, K.M. \& Ara, I. 2008. Understanding the Monga in northern Bangladesh. Academic Press and Publishers Library, Dhaka.

Farrington, J., Holmes, R. and Slater, R. (2007) 'Linking Social Protection and the Productive Sectors'. ODI Briefing Paper 28. London: ODI.

Greeley, M. 1997. Poverty and well-being: problems for poverty reduction in role of credit in wood G and I Sharif 'Who Needs Credit: Poverty and Finance in Bangladesh', University Press Limited, Dhaka, Bangladesh.

Hye, H.A. 2002. Kepping Monga at bay. Dhaka: The Daily Star, Dhaka: 15 November 2002.

InM-PKSF. 2006-2007. "InM-PKSF Census Survey”, Institute of Microfinance and Palli karma Sahayak Foundation, Dhaka, Bangladesh.

Karim, R., \& Levinson, F.J. 1979. A missing dimension of food and nutrition policy in Bangladesh. Journal of BIDS, 7(1): 99-106.

Mazumder, M.S. \& Wencong, Lu. 2012. Monga vulnerability in the Northern part of Bangladesh. African Journal of agricultural research vol 7(3), pp. 358-366, 19 January, 2012

MoF. 2010. Bangladesh Economic Review (BER). Ministry of Finance, Government of the Peoples Republic of Bangladesh, Dhaka.

Paul S.K. 2014. Determinants of evacuation response to cyclone warning in coastal areas of Bangladesh: a comparative study. Oriental Geographer, 55(1-2):57-84.

Roy, D.K. 1996. Poverty alleviation and trade policy reform in Bangladesh: some related issues. Journal of BIDS, 24(1\&2): 189-205.

Sen, A. 1984. Poverty and famines: an essay on entitlement and deprivation. Oxford University Press, Delhi.

Zug, S. 2006. Monga-seasonal food insecurity in Bangladesh: bringing the information together. Journal of Social Studies, 111: 21-39. 